\title{
Article \\ Learning Sets Theory Using Shadow Puppet: A Study of Javanese Ethnomathematics
}

\author{
Rully Charitas Indra Prahmana * $\mathbb{D}$ and Afit Istiandaru
}

check for updates

Citation: Prahmana, R.C.I.; Istiandaru, A. Learning Sets Theory Using Shadow Puppet: A Study of Javanese Ethnomathematics.

Mathematics 2021, 9, 2938.

https://doi.org/10.3390/ math9222938

Academic Editor: Jay Jahangiri

Received: 11 October 2021

Accepted: 12 November 2021

Published: 18 November 2021

Publisher's Note: MDPI stays neutral with regard to jurisdictional claims in published maps and institutional affiliations.

Copyright: (c) 2021 by the authors. Licensee MDPI, Basel, Switzerland. This article is an open access article distributed under the terms and conditions of the Creative Commons Attribution (CC BY) license (https:/ / creativecommons.org/licenses/by/ $4.0 /)$.
Mathematics Education Department, Faculty of Teacher Training and Education, Universitas Ahmad Dahlan, Jl. Pramuka 42, Yogyakarta 55161, Indonesia; afit.istiandaru@pmat.uad.ac.id

* Correspondence: rully.indra@mpmat.uad.ac.id; Tel.: +62-812874477886

\begin{abstract}
Some countries have puppet culture in various forms, terms, and ways, including Indonesia. As a country with a diverse culture, it has detailed and comprehensive characteristics and stories related to puppets, especially the Javanese shadow puppet. Some experts have explored its characteristics and found out that it contains many mathematical elements which could be used as a starting point to learn mathematics. The elements, however, still focus on the exploration of geometry material. We hardly find any other material that has been explored as deep as the geometry material in the context of the Javanese shadow puppet. Therefore, this study aims to explore the other elements of mathematics potentially found in this context which—for this example—is the sets material. Besides, this study also discusses the righteous life values that the students could internalize during mathematics learning through shadow puppet culture. We used ethnography to explore it through literature study, documentation, and field notes. We found some interesting elements, characteristics, and patterns in the Javanese shadow puppet, which can be used as a starting point to learn the sets concept. Furthermore, the values and philosophy of the shadow puppet culture harbor the potential to foster the students' good character and behavior.
\end{abstract}

Keywords: ethnomathematics; Javanese shadow puppet; righteous values; character education; sets theory

\section{Introduction}

Indonesia is an archipelagic country that has a diverse culture. The culture is a manifestation of the rules and entertainment for the community and contains noble values. We can find such values in the culture of wayang kulit-the Indonesian Javanese shadow puppet.

The shadow puppet is not just entertainment. The Javanese uses it as a communication medium to deliver a message about life's wisdom to the public [1-3]. Additionally, the shadow puppet contains several mathematical elements which the Indonesian people have used to self-learn, such as number pattern and sets [4,5]. It is an opportunity for teachers to use it as a local context to increase the students' critical reasoning and motivation to learn mathematics. Thus, students can reinvent mathematics that is derived from their surrounding culture.

The puppet story is a literature masterpiece containing local wisdom described through the puppet characters [6]. We can see the local wisdom expressed through the conversation among characters and the scenes of the story. The wisdom may take the form of unggah-ungguh basa (politeness in speaking), subasita (polite manner), and the moral message. The shadow puppet also has protagonist characters, antagonist characters, tritagonist characters, and extra.

The initial scene in a shadow puppet performance is marked by the presence of jejer kedhaton (situation of a place). Then, a dalang (puppeteer) introduces the paraga (characters) along with the rise of conflict and ends with a resolution [7]. The manifestation of the knight characters is shown in the heroic actions when a problem arises. The knight character is a 
central figure to achieve victory. The existence of a knight becomes a legitimate sign of the power to control an area for the sake of achieving the kingdom's glory.

There are several puppet cultures in various countries. The potehi is a kind of puppet that originated from China which is made of fabric. The potehi talks about the classic stories of the Chinese dynasty [8]. Furthermore, a puppet from the Ottoman Empire tells the story of two careless workers of a mosque construction who then received sanctions from the empire [9]. The Aragoz puppet from Egypt is a small-wooden glove puppet made of camel skin and talks about criticism in some aspects of life [10]. In Europe, there are also shadow puppets adapted from the Chinese and Turkish puppets. It was in the form of a black shadow puppet [11]. In Southeast Asia, such as Malaysia, Thailand, and Cambodia, there are also shadow puppets influenced by Indonesian shadow puppets, which tell the story of the Ramayana and Mahabharata [11-14].

The originality of the shadow puppet culture is still being debated to the present. The shadow puppet culture is better known as Indonesian culture in the world's eye, though most of the story is adopted from the original story in India. Many say that it was the Indian kings who brought the puppet culture to Indonesia [11]. It is due to the Indonesian puppet culture is much more developed and sophisticated when compared to Indian or other countries.

The Indonesian puppet stories originated from the Indian epics of Mahabharata and Ramayana [11]. The Mahabharata was composed by Rsi Wiyasa, while the Ramayana was composed by Rsi Walmiki [15]. In the 10th century, the epic of Ramayana in Central Java was translated from Sanskrit into Old Javanese at the time of King Dyah Balitung [16]. Meanwhile, the epic of Mahabharata was translated into Old Javanese during the reign of King Dharmawangsa Teguh in East Java several centuries later [17]. The Mahabharata story is rich in values, such as human interest to independence, health, wealth, happiness, struggle, and personal determination to achieve goals [18]. In general, it appears that good will always win against evil. The Mahabharata also provides noble values, such as obedience and discipline in carrying out religion or government orders. The values are then become an example in society [19]. It also contains ethical values philosophically rooted in the belief in the Almighty God and that transcendental power determines all human destiny [20].

On the other side, the Indonesian puppet is accompanied by gamelan musical ensembles and stands out as the prominent art in Java, while the Indian puppet has little or no music. Chen [11] explains that puppet culture is only found in Indonesia and in several places where Hinduism has developed or survived in the region. Brandon [21] noted that the existence of the first Indonesian puppet was written in two royal copper plate charters. The first charter, dated $840 \mathrm{AD}$, mentions six people who may have been puppet players. Then, the second charter, dated $907 \mathrm{AD}$, describes the dance and epic recitation of a performance that may be a puppet show [11,22,23].

The idea to use shadow puppet as a mathematics learning context is in line with the ideas of Freudhental [24] and D'Ambrosio [25], that mathematical concepts come from the way humans respond to their surrounding environments, such as when they seek explanations, understanding, and solutions to various phenomena. Mathematics is influenced by historical, environmental, social, geographical, and cultural aspects in humans' life. Therefore, mathematics cannot construct itself [26]. It is also in line with the opinion of Alangui [27] and Muhtadi et al. [28] which state that mathematics is very close to human culture and daily life, which becomes a formal form. Unfortunately, mathematics becomes rigid, inflexible, and distant from human culture and daily life when it comes to formal form.

The formal mathematics at the end makes a huge gap between the theory and its reference to culture and students' daily life [25,29]. The school mathematics tends only to become a transfer of knowledge, while the students only accept without being encouraged to think critically, creatively, and reflectively on the knowledge they learn and acquire $[4,30]$. 
Thus, some efforts are needed to reconnect the elements contained in culture into the school mathematics learning.

D'Ambrosio [31] initiated the ethnomathematics approach as an alternative to cut the distance between formal mathematics and the students' daily life. Ethnomathematics is a way to learn and combine ideas, methods, and techniques used and developed by socio-cultural actors within a community to learn mathematical concepts [30,32]. This approach aims to reconstruct mathematics so that it comes back to its different cultural roots. Thus, the students can appreciate various cultural groups' different mathematical methods, ideas, and techniques [31]. This approach can foster the students' critical, democratic, and tolerant reasoning ability to various ideas found during the learning and outside school activities $[4,30]$. Therefore, ethnomathematics can be used as a learning innovation that makes the students love mathematics more, motivated to learn, and be more creative through their culture.

Some researchers have documented their study results related to the use of cultural contexts in mathematics learning. Rahmawati [33] studied the use of the Gadang house of Minangkabau to learn the Pythagorean theorem. Putra, Wijayanto, and Widodo [34] studied the Soko Tunggal mosque context to learn two-dimensional geometry. Nursyahidah, Saputro, Albab, and Aisyah [35] studied the use of Gunungan Megono to learn about cones. Prahmana, Yunianto, Rosa, and Orey [36] studied the pranatamangsa system and predictions for the anniversary of death and birthday in Javanese culture. Moreover, Nurjanah, Mardia, and Turmudi [37] studied Marosok trading tradition to develop the students' mathematical representative ability. In addition to this, the usage of puppet context in mathematics learning also have been developed. DeJarnette, Lausell, and Gonzalez [38] explored the similarity and dilation between the puppet and its reflection on the screen. Putri, Tanto, and Kusumasturi [39] explored the geometrical objects in the puppet characters. They found that the shape of the puppet characters could be reconstructed into some geometrical objects. Finally, Risdiyanti and Prahmana [5] designed learning using the context of the puppet as the starting point to learn sets of material. Those studies provide many insights into the use of various cultural contexts to learn various topics in mathematics. However, very limited number of researchers has explored the shadow puppet culture as a context for the starting point to learn about the sets theory and righteous values for students' character building. Under the idea of D'Ambrosio [31], we could see that the Javanese shadow puppet is potentially rich of ethnomathematics context in terms of the way the puppeteer applies the concept of sets in classifying the puppet characters using various characteristics. Thus, this study aims to explore ethnomathematics in the Indonesian Javanese shadow puppet culture, which can later be used as a starting point to learn about sets theory. Additionally, we would see if the values contained in the shadow puppet culture can be used to foster good attitudes and characters of the students.

\section{Methods}

This research used an ethnographic approach to understand a paradigm of life from the local's perspective to get their view about their world. It is in line with the ethnomathematics approach, which aims to explore mathematics ideas, methods, practices, and problem-solving carried out by members of a particular culture and their moral values $[40,41]$.

Ethnographic research involves learning activities about members of a culture who see, hear, speak, think, and act in different ways that they discover for themselves. It means that we did not only learn about a community culture but also learn from the culture. Thus, ethnographic research is appropriate to be used as a research method to explore ethnomathematics phenomena in the Indonesian Javanese shadow puppet culture.

We collected the data by conducting a literature review and photograph documentation to explore ethnomathematics elements in the shadow puppet culture. Through an extensive literature review [42-47], we focused on the use of Javanese standard version of Mahabharata story. It aims to make sure that the classification of the characters is clearly 
defined and to avoid subjectivity-the mandatory requirement in defining sets. From the huge information we got in the story, we mainly used the one about the characteristics of the puppet characters to connect them with the concept of sets. This procedure enabled us to group the characters into various sets and their relationship. The results of this exploration were then written in field notes to be analyzed descriptively and written in an ethnographic description.

\section{Results and Discussion}

After examining the Javanese shadow puppet culture using the ethnographic approach, we found that during the shadow puppet performance, the puppeteer arranges the characters using the concept of the set following the local community ideas, methods, and techniques passed down from generation to generation. Additionally, we also found a philosophy of life, moral values, and a way of life in the shadow puppet performance regarding the relationship among humans, between humans and nature, and between humans and God. It can be found in every story and appearance of a Javanese shadow puppet. Therefore, for the Indonesians, shadow puppet belongs to a complex art with its high artistic value and significant influence on people's lives.

\subsection{Concept of Sets in Arranging the Puppet Characters on the Screen of Kelir}

In a shadow puppet performance, a puppeteer put the characters on a white fabric screen called kelir. This screen is lighted by a lamp such that we can see all the characters' shadows from behind. It is the condition from which this puppet gets its name. The puppeteer puts the puppet characters on the right side and left sides, as shown in Figure 1.

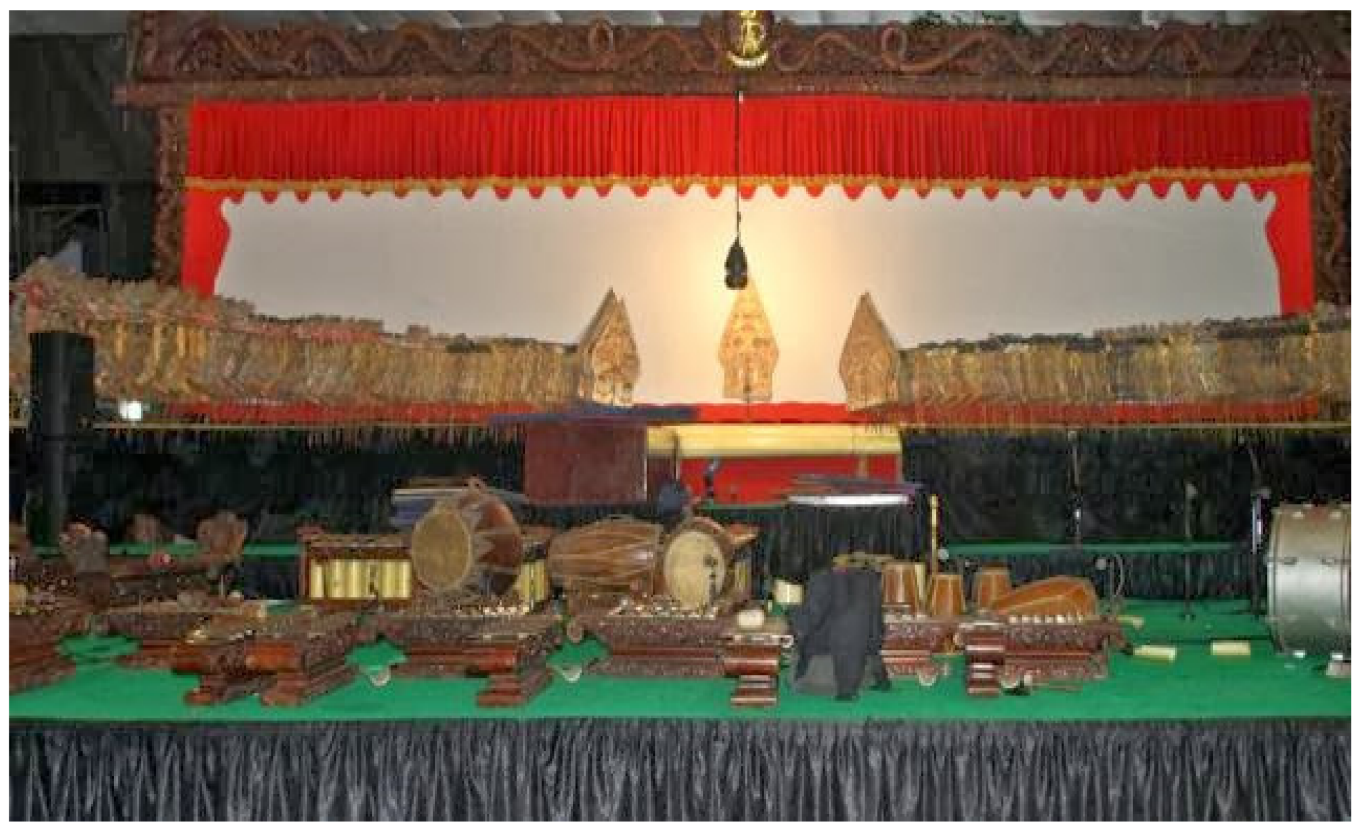

Figure 1. Puppet kelir seen from the front. Source: https:/ /id.m.wiktionary.org/wiki/kelir\#/media/ Berkas\%3Akelir.jpg (accessed on 17 September 2021).

This arrangement adds aesthetic value to the puppet show, illustrates the balance in life, makes it easier for the puppeteer to run the puppet during the show, and describes each paraga [42]. The arrangement on the sides of the screen is called simpingan. The puppet characters arranged on the right side of the screen are called simpingan kanan, while the puppet characters on the left side are called simpingan kiri. This arrangement is based on the dichotomy of right-left, good-bad, light-dark, which is known by the Indonesian Javanese people [43-45]. Based on the Javanese perspective, the right is interpreted as good things, while the left is interpreted as bad [46]. Simpingan kanan is arranged for puppets with good 
characters, while simpingan kiri is arranged for those with evil characters [44]. The two sides reflect the balance in life-there is the good, and there is the bad one.

Besides knowing the location either on the left side or the right side, we could recognize the puppet character from its shape [47]. Puppets with good characters have different visual characteristics to the ones with bad characters. Though some puppets may have mixed characters, we still could easily differentiate the original characteristics of the puppets as they show different visuals. For more details, we can see Figure 2.

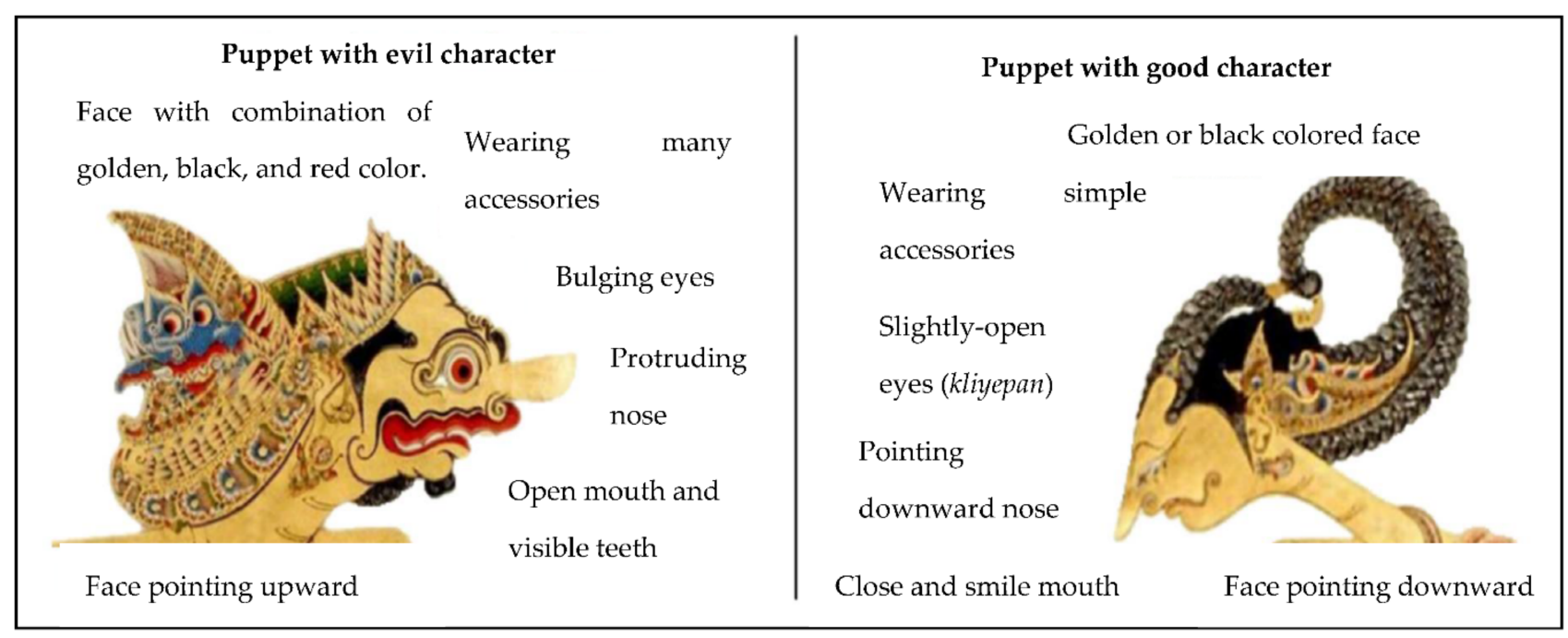

Figure 2. The puppet character is recognized from its visual.

Figure 2 shows the characteristics of puppets with good and evil characters. The visual characteristics describe the character's personality. The looking-up face usually describes the arrogant puppet character, while the looking-down face describes the lowprofile character. However, sometimes we also found puppet characters with their face pointing straight ahead. It describes their personality of staying alert. Furthermore, we can interpret the head accessories used by the characters as well. The character with lots of accessories tends to spend and waste money, while the character with few and simple accessories tends to spend money wisely.

The color of the puppet's face also reflects the character's personality. The main color of the puppet's face is generally golden, whether it is evil, good, knights, kings, or gods. Knights and kings usually have golden face color as it shows authoritative, wise, and noble personalities. Additional color may define and emphasize the characters' personalities. Puppets with black faces depict a strong personality, red faces depict evil personalities filled with anger, turquoise faces depict coward and arrogant personalities, and white faces depict subtle and honest personalities.

Additionally, puppet characters' personalities can be seen from the shape of their eyes, nose, and mouth. The wise characters usually have kliyepan (slightly open) eyes which means noble and wise, while the ones with bulging eyes depict the cunning, deceitful, harsh, angry, greedy, and mighty but evil characters. However, some knights also have bulging eye shapes interpreted as humble, virtuous, agile, tough, and defends the truth. Based on the nose shape, the puppet with a prominent nose shape usually depicts the character of spontaneous and rude, while the ones with a sharp nose describe the calm and gentle character. Finally, the puppet characters can also be seen from the shape of their mouth. The puppet with an open mouth and visible teeth depicts the harsh character, while the one with a closed and smile mouth describes the soft and gentle character.

The first example is the character of Yudhistira or Puntadewa in the Javanese version story of Mahabharata. Puntadewa is the first child of King Pandu Dewanata and Kunti. Along with his four siblings-Werkudara (Bhima), Janaka (Arjuna), Nakula, and 
Sadewa-they are known as Pandhawa (Pandavas). When he grew up, he became a king in Amartapura (Indraprastha) Kingdom. Amartapura was victorious, and its people lived in peace and prosperity led by Puntadewa. We can see his puppet in Figure 3.

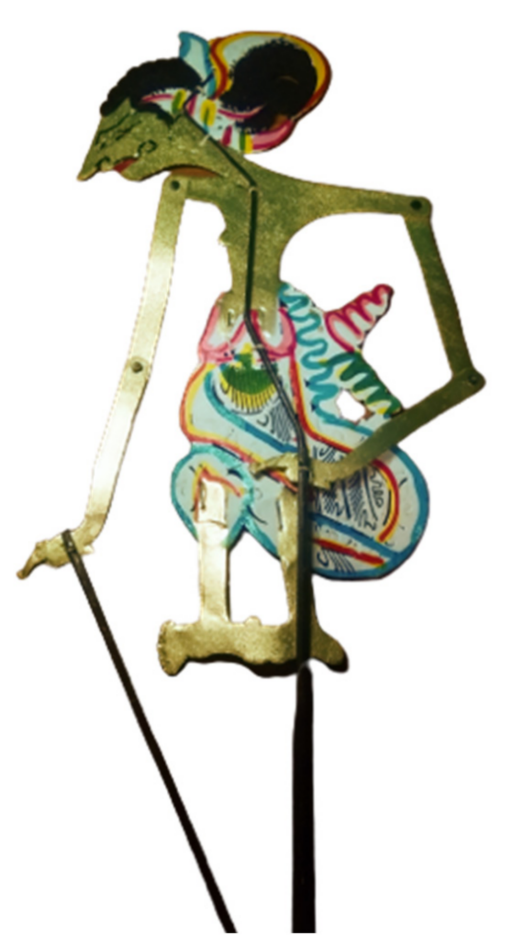

Figure 3. Puntadewa or Yudhistira.

Figure 3 shows that Puntadewa has a golden face that describes authority, wiseness, and noble. His head is looking down, which means he is a low-profile character. He also wears simple head accessories, which means he is not extravagant. His eyes are slightly open, which means that he is wise. His sharp nose also describes that he is calm and gentle. Finally, the shape of Puntadewa's mouth is closed and smile, which describes Puntadewa's character to be soft and gentle when speaking. Overall, he represents a good character in the story.

The following example is the character of Shakuni or Sengkuni in the Javanese version of the Mahabharata story. Sengkuni is a crown prince of Gandara Kingdom. His sister, Gandari, married the crown prince of Hastinapura, Destrarasta, by a misunderstanding process. The Gandara family never expects that Gandari will marry the blind crown prince instead of the younger brother, Pandu. That is why Sengkuni had a grudge against the Hastinapura family, especially Pandu. Sengkuni then vowed to make Pandu Dewanata and his descendants live in misery. The appearance of Sengkuni puppet is shown in Figure 4.

Figure 4 shows that Sengkuni has a red face, referring to his evil character and filled with anger. The position of Sengkuni's head is looking up, illustrating that he is arrogant and crafty. The accessories on his head are full of knick-knacks, which describes his character who likes to waste anything. The shape of his bulging eyes describes his sly character, likes to cheat, hard, full of wrath, greed, and mighty but vile. Furthermore, Sengkuni has a prominent nose shape which describes his spontaneous and often rude character. Sengkuni also has an open mouth and visible teeth, which illustrates his loud and rough speech. All characteristics shown in the Sengkuni puppet show that Sengkuni has a bad character.

This research explores the arrangement of puppets on the kelir screen during the performance of Mahabharata's story. The Mahabharata story tells about the sibling conflict between Pandhawa and Kurawa over the Kingdom of Hastinapura. In the story, there 
are 45 books with 162 characters [8]. However, this study focused on exploring the main characters as an example of the puppet arrangement on the screen.

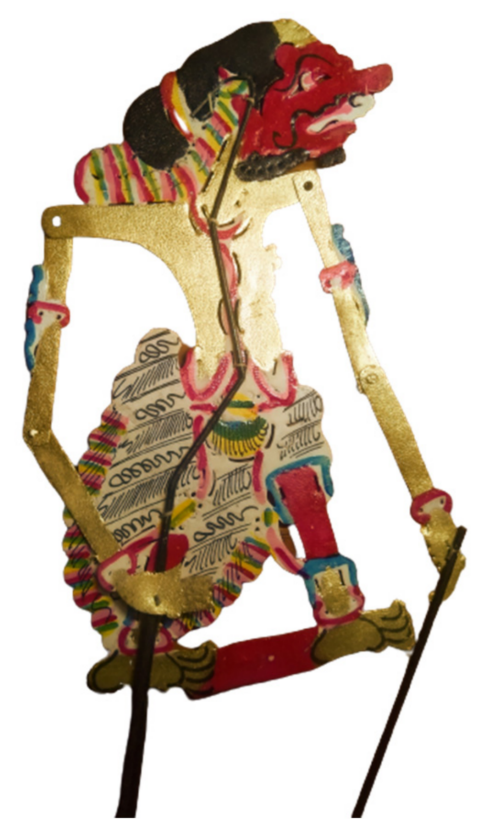

Figure 4. Sengkuni or Shakuni.

The main characters include Puntadewa, Bima, Arjuna, Nakula, Sadewa, Duryudana, Dursasana, Kertamarma, Citraksa, Citraksi, Dewi Amba, Dewi Kunti, Dewi Gandari, Srikandi, Pandu Dewanata, Sengkuni, Bhisma, Destrarasta, and Krishna. The illustration of these characters can be seen in Figure 5.

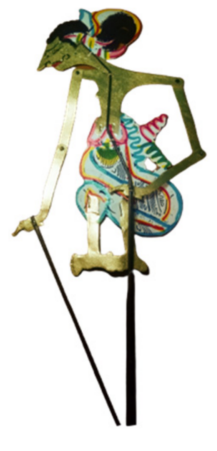

Puntadewa

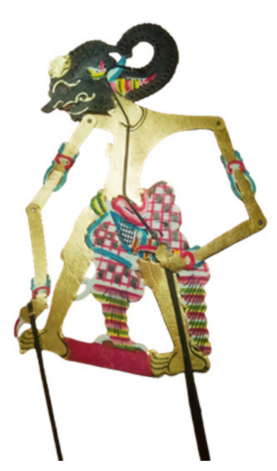

Bima

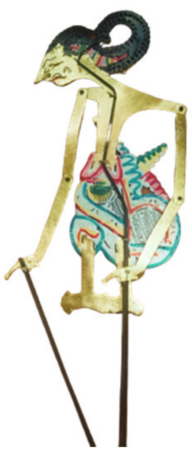

Arjuna

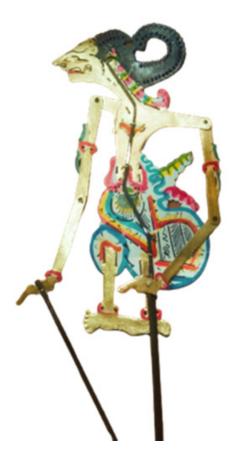

Nakula

Figure 5. Cont. 


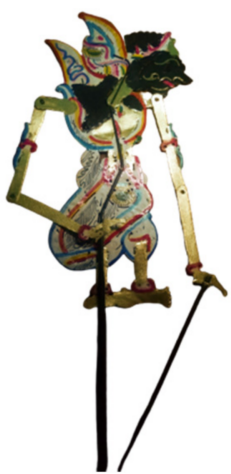

Duryudana

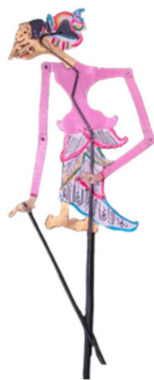

Dewi Amba

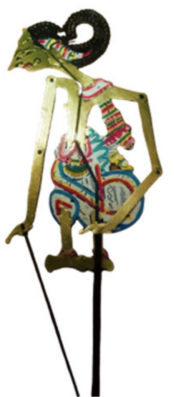

Pandu Dewanata

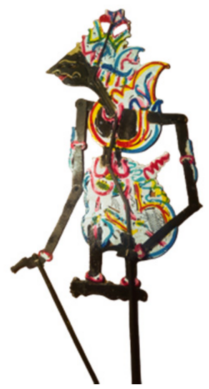

Kresna

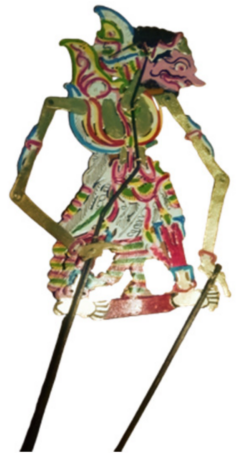

Dursasana

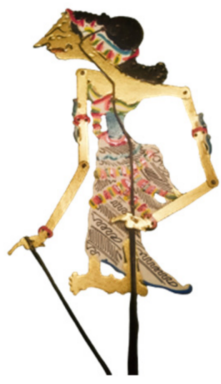

Dewi Kunti

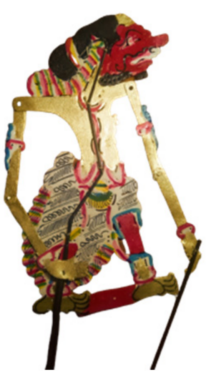

Sengkuni

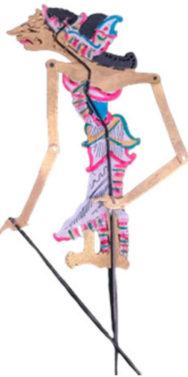

Srikandi

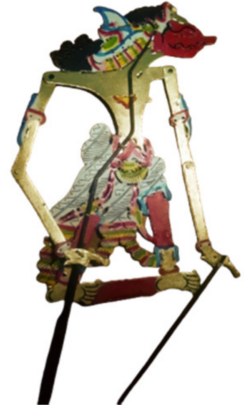

Kertamarma

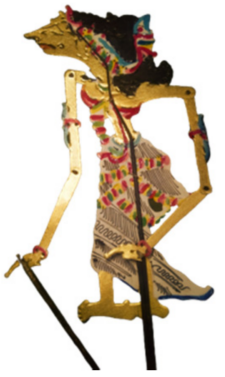

Dewi Madrim

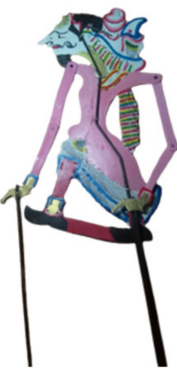

Bhisma

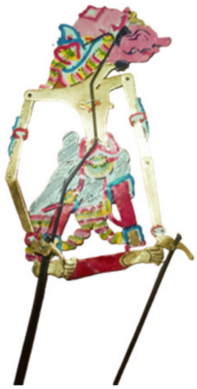

Citraksi

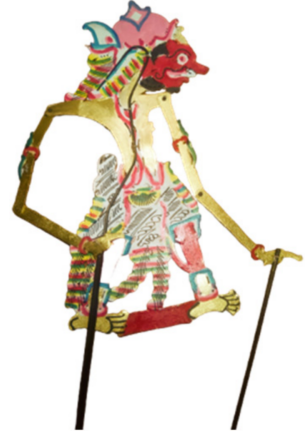

Citraksa

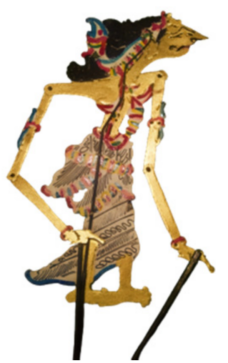

Dewi Gandari

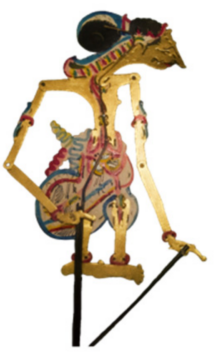

Destrarasta

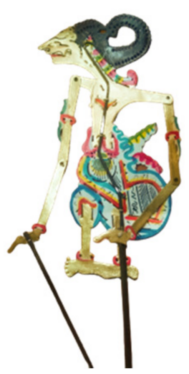

Sadewa

Figure 5. The puppet of main characters in Mahabharata story.

In the arrangement of characters on the kelir screen, the left side consists of puppets with bad characters, and the right side consists of puppets with good characters. Whether or not it is consciously arranged, a puppeteer has used the concept of the sets to arrange the puppet characters on the screen during the shadow puppet show. It is defined as a clearly defined collection of objects [48,49]. With the methods and ideas of the Javanese people themselves, they have collected objects in the arrangement of characters on the screen, which they have clearly defined. 
The puppeteer collects the characters of Mahabharata and arranges the bad characters on the left side while the good characters on the right side. It should be noted that the terms of good and bad are subjective and risky in defining the elements of the sets. However, in classifying the good and the bad in the Mahabharata story, Javanese people have already had a consensus on which characters are good and bad based on the Javanese version of Mahabharata stories and various characteristics explained in Figure 2. Thus, such bias can be easily avoided in defining the sets.

The sets that contain all the defined objects are called the universal set. Thus, when the puppeteer groups all the puppets in the story of Mahabharata, he is indirectly using the concept of a universal set that in mathematical form can be denoted as follows.

Sets of Mahabharata characters $=\{$ Puntadewa, Bima, Arjuna, Nakula, Sadewa, Duryudana, Dursasana, Kertamarma, Citraksa, Citraksi, Dewi Amba, Dewi Kunti, Dewi Gendari, Srikandi, Pandu Dewanata, Sengkuni, Bhisma, Destrarasta, Kresna\}.

We can also introduce the set notation. Let $S$ denotes the set of all Mahabharata puppet characters, we can express this set in to set notation as follows.

$$
S=\{x \mid x \text { is a Mahabharata puppet character }\}
$$

Furthermore, the members of simpingan kiri and simpingan kanan can be seen from the illustration of each character. Simpingan kiri is a set of puppets with bad characters. Its members are Duryudana, Dursasana, Kertamarma, Citraksa, Citraksi, Dewi Gendari, and Destrarasta, as shown in Figure 5.

Meanwhile, the set of simpingan kiri can be expressed in mathematics as follows.

Simpingan Kiri $=\{$ Duryudana, Dursana, Kertamarma, Citraksa, Citraksi, Dewi Gendari, Destrarasta\}.

Let $A$ denotes a member of simpingan kiri, we can express this set into the notation as follows.

$$
A=\{x \in S \mid x \text { is a member of simpingan kiri }\}
$$

Simpingan kanan is a set of puppets with good characters. Its members are Puntadewa, Bima, Arjuna, Nakula, Sadewa, Dewi Amba, Dewi Kunti, Dewi Madrim, Srikandi, Krishna, Pandu Dewanata, dan Bhisma, as shown in Figure 5. The set of simpingan kanan can be expressed in mathematics as follows.

Simpingan Kanan $=\{$ Puntadewa, Bima, Arjuna, Nakula, Sadewa, Dewi Amba,

Dewi Kunti, Dewi Madrim, Srikandi, Krishna, Pandu Dewanata, Bhisma\}.

Let $B$ denotes a member of simpingan kanan, we can express this set into the notation as follows.

$$
B=\{x \in S \mid x \text { is a member of simpingan kanan }\}
$$

In the screen arrangement, the puppets with bad characters are on the left side facing to the left, and the puppets with good characters are on the right side facing to the right illustrated in Figure 1. However, when the puppet plays a role, the puppet with the evil character faces the right, and the puppet with the good character faces the left.

In the story of Mahabharata, there are several groups of puppets, such as the Pandhawa and the Kurawa. Pandhawa is the five sons of King Pandu Dewanata with Dewi Kunti and Dewi Madrim, who are incarnations of gods, who when they grow up become a knight [8]. Pandhawa has a good character. Thus, in the character arrangement on the screen, Pandhawa is on the right side. Meanwhile, Kurawa (Kauravas) is the a-hundred sons of Destrarasta and Dewi Gandari. Destrarasta was once a crown prince of Hastinapura but failed to get crowned due to his blind eyes. His younger brother, Pandu, became the one 
who took his place but died some years after that. Destrarasta finally became the temporary king with a promise that one day the king position would be passed to Puntadewa, the eldest son of Pandu. However, Kurawa tried hard to control the kingdom of Hastinapura and challenged Pandhawa to carry out the civil war of Bharatayuddha [8]. Thus, since Kurawa has a bad character, Kurawa's place is on the left side in the arrangement on the screen.

The set of Pandhawa consists of five members, i.e., Puntadewa, Bima, Arjuna, Nakula, and Sadewa. Meanwhile, Kurawa consists of 100 members. However, the main characters of Kurawa, who take the role in the story of Javanese Mahabharata, are only five representatives, i.e., Duryudana, Dursasana, Kertamarma, Citraksa, and Citraksi (See Figure 5). Both the set of Pandhawa and Kurawa can be expressed mathematically as follows.

$$
\begin{aligned}
& \text { Pandhawa }=\{\text { Puntadewa, Bima, Arjuna, Nakula, Sadewa }\} \\
& \text { Kurawa }=\{\text { Duryudana, Dursasana, Kertamarma, Citraksa, Citraksi }\}
\end{aligned}
$$

Let $P$ denotes a member of Pandhawa, we can express this set into the notation as follows.

$$
P=\{x \in S \mid x \text { is a member of Pandhawa }\}
$$

Furthermore, let $K$ denotes a member of Kurawa, we can express this set into the notation as follows.

$$
K=\{x \in S \mid x \text { is a member of Kurawa }\}
$$

Looking at the sets of Pandhawa and the sets of simpingan kanan, we can see that all members of the Pandhawa are members of simpingan kanan. In the basic concept of the sets, we have the term subset, a condition where all set members are members of another sets $[48,49]$. Thus, it can be concluded that Pandhawa is a subset of simpingan kanan. On the other hand, we can also see that all members of Kurawa are also members of simpingan kiri. Therefore, we can say that Kurawa is a subset of simpingan kiri. We can express it mathematically as follows.

$$
\begin{aligned}
& \text { Kurawa } \subset \text { Simpingan Kiri } \\
& \text { Pandhawa } \subset \text { Simpingan Kanan }
\end{aligned}
$$

Let $K$ denotes a set of Kurawa and $A$ denotes a set of Simpingan Kiri, we can express the correlation between Kurawa and Simpingan Kiri into the notation as follows.

$$
K \subset A
$$

Furthermore, let $P$ denotes a set of Pandhawa and $B$ denotes a set of Simpingan Kanan, we can express the correlation between Pandhawa and Simpingan Kanan into the notation as follows.

$$
P \subset B
$$

Using the characteristics of the previous defined sets, we could also introduce about the operation of sets, such as union, intersection, and complement. It is clear that the set of all Mahabharata characters is the union of the set of puppet characters in Simpingan Kiri and Simpingan Kanan. Mathematically, we may denote as follows.

$$
\text { Set of Mahabharata characters }=\text { Simpingan Kiri } \bigcup \text { Simpingan Kanan }
$$

Furthermore, we can express the notation of the union of the set as follows.

$$
S=A \cup B=\{x \mid x \in A \vee x \in B\} .
$$


If we have any two sets. The set intersection between that two can be defined as the member which belongs to both. In this case, we can take an example, since the Pandhawa members are contained in the set of Simpingan Kanan, we can illustrate as follows.

$$
\text { Pandhawa }=\text { Pandhawa } \bigcap \text { Simpingan Kanan }
$$

We can also express the notation of the intersection of the set as follows.

$$
P=P \bigcap B=\{x \mid x \in P \wedge x \in B\}
$$

It follows from the property of the set of all characters in simpingan kanan that we may deduce that the set of all characters in simpingan kiri is the complement of the set of all characters in simpingan kanan. Since the set of Mahabharata characters = Simpingan Kiri $\bigcup$ Simpingan Kanan, then,

$$
\text { Simpingan Kiri }=\{\text { Simpingan Kanan }\}^{c}
$$

Moreover, we can introduce the concept of empty set. It follows from the membership of Pandhawa and Kurawa, we know that there is no a puppet character which belongs to both sets. Hence,

$$
\text { Pandhawa } \bigcap \text { Kurawa }=\varnothing
$$

\subsection{Noble Values in the Shadow Puppet Performance}

Besides the concept of the sets, we found in the Javanese puppet culture, we also noticed that the puppet culture contains meaningful messages about philosophy, morality, and behavior teachings of humans in relation with the other human, nature, and God. The shadow puppet culture has been deeply embedded in the community since the days of their ancestors [50,51].

Puppet has been passed down from generation to generation and has become an art that is not only known by the Indonesian people but also by the world [11,52]. The puppet is not just entertainment for the Indonesians. As an art, people can understand and reflect on the philosophy of life, moral, behavior, and way of life [20,53]. Therefore, it is undeniable that the influence of puppets on the life of Javanese people is huge. The Javanese makes significant adaptation to the stories and tailor it to be more relevant with Javanese values. The rules for becoming a puppeteer have been inherited and become a tradition. For example, when delivering the story, a puppeteer also conveys good teachings such as leadership. When a puppeteer conveys the leadership teaching, he will emphasize the characters of Surya, Chandra, Kartika, Akasa, Kisma, Tirta, Dahana, and Samirana or known as Asthabrata [54].

An attractive and entertaining shadow puppet performance can make the audience happy, but the function of the puppet cannot be narrowed down only as artistic entertainment but also functions as a means of education and communication to deliver messages to the community [1-3]. Thus, the shadow puppet performance contains educational values that are useful for humans in society. The ancestors instilled these values through a shadow puppet show that was easily accepted by the public, entertaining, and educative.

Furthermore, the Indonesian people also interpret the shadow puppet to reflect the universe's life [55]. The puppet then becomes interesting, beautiful, and acceptable to deliver and educate the community's values $[20,52,55,56]$. These values then affect the ethics and aesthetics of society in real life. Indonesian people also interpret puppet as a performance that contains all aspects of life, or in Javanese terms, it is called momot kamot [55]. The puppet culture also includes many aspects of the human mind regarding ideology, politics, economics, social, culture, law, defense, and security through the flexibility of the puppeteer in reconstructing actual problems in society in his performance [55]. 
The puppet story tells about an ideological system that aspires to build a prosperous country in the form of a kingdom [57]. Additionally, the story describes the dualism in life, namely the good and the bad, the wisdom and the evil, and religious systems [18].

The puppet story generally raises the theme of the battle between the good and the bad, promoting justice over the injustice, the truth over the lies in human life $[55,58,59]$. Religious values, science, philosophy, and art are the fundamental values firmly held by the puppeteers $[1,55]$. Then the actual problems in everyday life are discussed in a relaxed segment, such as the limbugan and gara-gara (humor segment).

The earliest shadow puppet was found in Java, and the Indian influence may lie in the adaptation of the great Indian stories-the Mahabharata and the Ramayana $[11,60]$. The influence of these stories is not only in Indonesia but also in Southeast Asian countries where Hinduism has ever been developed there. In Indonesia, people also include the indigenous local animistic Javanese ancestors and several local Javanese values in the puppet performances. Thus, the puppet stories become more Javanese rather than Indian [11]. Moreover, it is also believed that the puppet culture in Cambodia, Thailand, and Malaysia may originate or be influenced by the Indonesian puppet culture [11,12,61].

From time to time, the epics of Mahabharata and Ramayana were developed and composed in poetry, prose, and performance script [16]. Earlier, the essence of the Mahabharata and Ramayana story rests on Hinduism teachings. Later, when Islam entered the land of Java, its contents, characters, and stories changed and created a harmonious blend of the concept of humanity. Although it has been through many adaptations, the Javanese moral teachings remain the essence of the two epics [16]. Many puppeteers also add their versions or composition into some scenes of the story. These added versions enrich the development of puppet culture as well as its teachings of noble values.

\subsection{Ethnomathematics and Character Education in Puppet Culture}

The shadow puppet contains mathematical concepts which can be used as a context in learning the basic concepts of sets starting from concrete things that students can imagine. Through the context of shadow puppet, the process of developing ideas and concepts of the sets from a real context or conceptual mathematization can be carried out to produce mathematical knowledge from concrete things that are close to students' daily life. The use of real context is important to guide students to progress from one level of thinking to the next level. De Lange [62] explains that there are three levels of the students' thinking process. First, the students can manipulate the characteristics of the things they know. Second, the students can manipulate the relationships of these characteristics. Third, the students can manipulate the intrinsic characteristics of these relationships. Students can be assisted with real contexts-the shadow puppet context-to reach the first level. It is due to the shadow puppet is familiar to the students in Indonesia, especially in Java. To reach the second level, students can understand and classify the good and bad characters of puppets based on the arrangement of kelir screen. At the third level, students can determine and define several sets theory of relationships between characters [5].

Using puppets as a real context in learning mathematics is in line with the Realistic Mathematics Education (RME) approach. The RME emphasizes the relationship of mathematics to the reality that is close to the students' experience and relevant to society to become a human value. Mathematics is essentially a human activity and must be related to daily reality $[24,63]$. In the RME approach, one of the real contexts can be the results of exploratory ethnomathematics studies. For example, Risdiyanti and Prahmana [5] reveals in their work using RME approach relate to the relationship among student learning path, learning activities and the basic concepts of sets using puppets are showing in the Table 1 and adapted it to the needs of this research. 
Table 1. The learning activities using the Indonesian shadow puppets.

\begin{tabular}{|c|c|c|c|c|}
\hline RME Levels & Students Learning Paths & Learning Activities & Set Basic Concepts & Noble Values \\
\hline $\begin{array}{l}\text { Real Situation to } \\
\text { Model of }\end{array}$ & $\begin{array}{c}\text { Activity } 1 \\
\text { Watching Mahabrata } \\
\text { puppet stories }\end{array}$ & $\begin{array}{l}\text { Watching and identify } \\
\text { the character of the } \\
\text { Mahabharata puppet }\end{array}$ & Universal set & $\begin{array}{l}\text { The puppet stories could } \\
\text { maintain the } \\
\text { community identity }\end{array}$ \\
\hline $\begin{array}{l}\text { Model of to } \\
\text { Model for }\end{array}$ & $\begin{array}{c}\text { Activity } 2 \\
\text { Composing the } \\
\text { Mahabrata puppet in the } \\
\text { kellir screen }\end{array}$ & $\begin{array}{l}\text { Understanding the } \\
\text { pattern, arrange the } \\
\text { puppet in the kellir } \\
\text { screen Classifying the } \\
\text { puppet based on the } \\
\text { evil or good characters } \\
\text { Classifying the puppet } \\
\text { of five groups of } \\
\text { Pandhawa } \\
\text { and Kurawa }\end{array}$ & Subsets & $\begin{array}{l}\text { Understanding the good } \\
\text { attitude performed by } \\
\text { some puppet characters } \\
\text { could be adopted, while } \\
\text { the bad things should } \\
\text { be avoided }\end{array}$ \\
\hline $\begin{array}{l}\text { Model for to } \\
\text { Formal Knowledge }\end{array}$ & $\begin{array}{c}\text { Activity } 3 \\
\text { Write the set of } \\
\text { Mahabrata Puppet }\end{array}$ & $\begin{array}{l}\text { Define the sets, the } \\
\text { member of sets, } \\
\text { subsets and write all } \\
\text { informal form }\end{array}$ & $\begin{array}{l}\text { Definition and formal } \\
\text { form of sets, members } \\
\text { of sets and subsets }\end{array}$ & $\begin{array}{l}\text { Enhance students' } \\
\text { understanding of the } \\
\text { relation between the } \\
\text { puppets' characters and } \\
\text { their position on the screen. } \\
\text { Students will learn the } \\
\text { philosophy of life that } \\
\text { good people will be meet } \\
\text { and become one as a group } \\
\text { and vice versa. }\end{array}$ \\
\hline
\end{tabular}

As part of Indonesian culture, the shadow puppet is part of ethnomathematics studies' exploration results, which recognize that Javanese culture can be used as media to develop ideas, techniques, methods, and practices to learn about set through the arrangement of puppet characters on the screen. Additionally, the shadow puppet culture contains values, morality, and views of life that can be explored and become an example for students. D'Ambrosio [64] stated that learning about concrete problems and instills the desire to seek the solution for humankind can make the students appreciate and recognize more about their culture. Finally, the results of such learning can easily assimilate the culture and mathematics learning by critically reflecting on the values embodied in the culture.

Puppetry can be used to shape the good character of students since it contains not only artistic values but also noble values [20]. Students could understand that the good attitude performed by some puppet characters could be adopted, while the bad things should be avoided. The use of puppet stories in learning is also a substantial effort to maintain the community identity so that the next generation does not forget the puppet culture.

Moreover, the puppet performance belongs to the art of storytelling [65]. The use of storytelling in learning could make the learning activities more interesting than the conventional ones. Instead of only reading a textbook, teachers could be good storytellers to deliver the book. Teachers could easily connect the learning material to the actual context used in the story. It makes the students easily imagine the context by using the puppets as a model for bridging what they learn in and out of the school. As a result, the students could be happier to learn and understand better [65]. The elders of Indonesia also support using the puppet as the learning media due to a strong reason that later the students will more appreciate their culture as part of their identity [66,67].

Some researchers have developed mathematics learning using puppet context. Dejarnnette, Lausell, and Gonzalez [38] explored the similarity and dilation between the puppet and its reflection on the screen. Putri, Tanto, and Kusumasturi [39] explored the geometrical objects in the puppet characters. They found that the shape of the puppet characters could be reconstructed into some geometrical objects. Finally, Risdiyanti and 
Prahmana [5] designed learning using the context of the puppet as the starting point to learn set material.

The results of this ethnomathematics exploration study contribute to complementing some previous studies that have examined ethnomathematics from various cultures in Indonesia [33,35-37,67-69]. Furthermore, these results could inspire the exploration of puppet culture in other countries for the same purposes as well. Thus, these findings can enrich the knowledge related to education and culture, especially a reference to real culturalbased contexts in Indonesia that can be used as a starting point in learning mathematics and enhancing students' character building by finding out noble values obtained at school.

\section{Conclusions}

The results of the ethnomathematics exploration of Indonesian Javanese shadow puppet culture found many basic concepts of sets, such as the definition of sets, universal sets, subsets, the union of the set, the intersection of the set, the complement of the set, and the concept of the empty set, which can be seen from the arrangement of the puppets on the screen (kelir). Starting the mathematics learning from the surrounding cultural phenomena is important. We could use it to reduce the gap of formal mathematics with the closest context the students could understand. By using this context, mathematics would be more interesting. Additionally, the Indonesian shadow puppet culture is rich in the philosophy of life, moral values, and an in-depth view of life, which can be used for the students' character education. These findings also enrich the development of ethnomathematics exploration in the Indonesian culture, such as in the material of geometry, number patterns, etc.

In addition, further research could be done to examine if the formal knowledge of the universal set could start as a new situation level to extend students' understanding of other topics. Furthermore, these results could inspire the exploration of puppet culture in other countries for the same purposes. The puppet culture contains mathematical concepts and local wisdom to promote the students' good character. Finally, these findings provide a promising context to learn about set and build students' good character for further research.

Author Contributions: Conceptualization, R.C.I.P.; methodology, R.C.I.P.; validation, R.C.I.P. and A.I.; formal analysis, R.C.I.P. and A.I.; investigation, R.C.I.P. and A.I.; data curation, R.C.I.P. and A.I.; writing—original draft preparation, R.C.I.P.; writing—review and editing, R.C.I.P. and A.I.; visualization, R.C.I.P. and A.I. All authors have read and agreed to the published version of the manuscript.

Funding: This research was funded by Universitas Ahmad Dahlan under the grant of Candidate Professorship Program.

Institutional Review Board Statement: Not applicable.

Informed Consent Statement: Not applicable.

Data Availability Statement: Not applicable.

Acknowledgments: We want to express our gratitude to Irma Risdiyanti, Puguh Wahyu Prasetyo, and Nur Robiah Nofikusumawati Peni for their assistance in improving, discussing, and photographing Wayang with high-resolution composition for the final version of this work. Furthermore, we also appreciate the anonymous reviewers and the associate editor's time, efforts, suggestions, and comments. Their recommendations were followed correctly and strictly, resulting in a significant improvement in the quality of our final paper. Finally, we'd like to thank Universitas Ahmad Dahlan for supporting and funding this work under the supported professorship candidate research grant.

Conflicts of Interest: The authors declare no conflict of interest.

\section{References}

1. Purwanto, S. Pendidikan nilai dalam pagelaran wayang kulit. Ta'allum J. Pendidik. Islam 2018, 6, 1-30. [CrossRef]

2. Soetarno, S. Makna pertunjukan wayang dan fungsinya dalam kehidupan masyarakat pendukung wayang. Dewa Ruci 2011, 7 , 300-332.

3. Ramli, W.N.R.W.; Lugiman, F.A. The contribution of shadow puppet's show through engaging social communication in modern society. Procedia Soc. Behav. Sci. 2012, 35, 353-360. [CrossRef] 
4. Risdiyanti, I.; Prahmana, R.C.I. The learning trajectory of number pattern learning using Barathayudha war stories and uno stacko. J. Math. Educ. 2020, 11, 157-166. [CrossRef]

5. Risdiyanti, I.; Prahmana, R.C.I. Designing learning trajectory of set through the Indonesian shadow puppets and Mahabharata stories. Infinity 2021, 10, 331-348. [CrossRef]

6. Sari, A.P. Filosofi karakter tokoh kesatria dalam lakon wayang purwa Mahabarata. Piwulang J. Pendidik. Bahasa Jawa 2021, 9 , 13-25.

7. Zaid, A. Javanese philosophy as an alternative in teaching character building. In Proceedings of the UNNES International Conference on ELTLT, Semarang, Indonesia, 8-9 October 2016; pp. 10-13.

8. Stenberg, J. Wayang potehi: Glove puppets in the expression of Sino-Indonesian identity. J. Southeast Asian Stud. 2015, 46, 391-416. [CrossRef]

9. Smith, J. Karagoz and Hacivat: Projections of subversion and conformance. Asian Theatre J. 2004, 21, 187-193. [CrossRef]

10. Hussein, N.H. The revitalization of the Aragoz puppet in Egypt: Some reflections. Pop. Entertain. Stud. 2012, 3, 57-70.

11. Chen, F.P. Shadow theaters of the world. Asian Folk. Stud. 2003, 62, 25-64.

12. Yousof, G.S. The shadow plays of Southeast Asia: Relationships between the various forms. SPAFA J. 2006, 16, 5-16.

13. Mishra, P. Cultural history of Indian diaspora in Cambodia. Int. J. Humanit. Soc. Sci. Invent. 2013, 2, 67-71.

14. Srisuchat, A. Mahabharata in art and literature in Thailand. Indian Lit. 2005, 49, 105-114.

15. Dewanto, M.R.; Widodo, W.; Savitri, S. Poster anti narkoba melalui karakter tokoh wayang dalam gaya seni psikedelik. Atrat J. Seni Rupa 2017, 5, 61-68.

16. Sunaryo, A. Rupa Wayang; CV Kekata Group: Surakarta, Indonesia, 2020.

17. Hall, K.R. Traditions of knowledge in old Javanese literature, c. 1000-1500. J. Southeast Asian Stud. 2005, 36, 1-27. [CrossRef]

18. Riantiarno, N. Mahabarata; Gramedia Widiasarana Indonesia: Jakarta, Indonesia, 2016.

19. Utorowati, S.; Sukristanto, S.; Israhayu, E.S. Nilai Pendidikan Karakter dalam Novel Mahabarata dan Novel Bisma Dewabrata: Sebuah Kajian Intertekstual. In Proceedings of the 8th University Research Colloquium (URECOL), Jawa Tengah, Indonesia, 4 September 2018; pp. 348-353.

20. Pramono, Y.L.; Suyanto, S.; Wahida, A. Shadow puppet arts as the formation of young generation character. In Proceedings of the International Conference on Art, Language, and Culture, Surakarta, Indonesia, 4 November 2017; pp. 397-404.

21. Brandon, J.R. On Thrones of Gold: Three Javanese Shadow Plays; University of Hawai's Press: Honolulu, HI, USA, 1993 ; pp. 15-21.

22. Tannenbaum, K. Carving Out a New Future: Waying Kulit Craftsmanship in Central Java, Indonesia. Ph.D. Thesis, University of Hawaii at Mānoa, Honolulu, HI, USA, 2018.

23. Khor, K.K. Digital Puppetry of Wayang kulit Kelantan: A study of its Visual Aesthetics/Khor Kheng Kia. Ph.D. Thesis, University of Malaya, Malaya, Malaysia, 2014.

24. Freudenthal, H. Revisiting Mathematics Education: China Lectures; Springer Science \& Business Media: Cham, Switzerland, 2006; Volume 9.

25. D'Ambrosio, U. Ethnomathematics: Perspectives. N. Am. Study Group Ethnomath. News 2007, 2, 2-3.

26. Risdiyanti, I.; Prahmana, R.C.I. Ethnomathematics: Exploration in Javanese culture. J. Phys. Conf. Ser. 2017, $943,012032$. [CrossRef]

27. Alangui, W.V. Stone Walls and Water Flows: Interrogating Cultural Practice and Mathematics. Ph.D. Thesis, University of Auckland, Auckland, New Zealand, 2010.

28. Muhtadi, D.; Sukirwan, S.; Warsito, W.; Prahmana, R.C.I. Sundanese Ethnomathematics: Mathematical activities in estimating, measuring, and making patterns. J. Math. Educ. 2017, 8, 185-198. [CrossRef]

29. Joseph, G.G. The Crest of the Peacock: Non-European Roots of Mathematics; Princeton University Press: New Jersey, NJ, USA, 2010.

30. D'Ambrosio, U. An overview of the history of Ethnomathematics. In Current and Future Perspectives of Ethnomathematics as a Program; Rosa, M., D’Ambrosio, U., Orey, D.C., Shirley, L., Alangui, W.V., Palhares, P., Gavarrete, M.E., Eds.; Springer: Cham, Switzerland, 2016; pp. 5-10.

31. D'Ambrosio, U. Ethnomathematics and its place in the history and pedagogy of mathematics. Learn. Math. 1985, 5, 44-48.

32. Rosa, M.; Orey, D.C. State of the art in Ethnomathematics. In Current and Future Perspectives of Ethnomathematics as a Program; Rosa, M., D'Ambrosio, U., Orey, D.C., Shirley, L., Alangui, W.V., Palhares, P., Gavarrete, M.E., Eds.; Springer: Cham, Switzerland, 2016; pp. 11-37.

33. Rahmawati, Y. Pendekatan matematika realistik bernuansa Etnomatematika: Rumah gadang minangkabau pada materi teorema pythagoras. J. Azimut 2020, 3, 22-29.

34. Putra, R.Y.; Wijayanto, Z.; Widodo, S.A. Etnomatematika: Masjid Soko Tunggal dalam pembelajaran geometri 2D. Pendidik. Mat. 2020, 4, 10-22. [CrossRef]

35. Nursyahidah, F.; Saputro, B.A.; Albab, I.U.; Aisyah, F. Pengembangan learning trajectory based instruction materi kerucut menggunakan konteks megono gunungan. Mosharafa J. Pendidikan Matematika 2020, 9, 47-58.

36. Prahmana, R.C.I.; Yunianto, W.; Rosa, M.; Orey, D.C. Ethnomathematics: "Pranatamangsa" system and the birth-death ceremonial in Yogyakarta. J. Math. Educ. 2021, 12, 93-112. [CrossRef]

37. Nurjanah, N.; Mardia, I.; Turmudi, T. Ethnomathematics study of Minangkabau tribe: Formulation of mathematical representation in the Marosok traditional trading. Ethnogr. Educ. 2021, 16, 1-20. [CrossRef] 
38. DeJarnette, A.F.; Lausell, S.L.R.; González, G. Shadow puppets: Exploring a context for similarity and dilations. Math. Teach. 2015, 109, 20-27. [CrossRef]

39. Putri, W.P.; Tanto, O.D.; Kusumastuti, N. Learning math through making shadow puppet. Int. J. Progress. Sci. Technol. 2021, 27, 342-347.

40. Shirley, L.; Palhares, P. Ethnomathematics and its Diverse Pedagogical Approaches. In Current and Future Perspectives of Ethnomathematics as a Program; Rosa, M., D'Ambrosio, U., Orey, D.C., Shirley, L., Alangui, W.V., Palhares, P., Gavarrete, M.E., Eds.; Springer: Cham, Switzerland, 2016; pp. 13-17.

41. Ascher, M.; D'Ambrosio, U. Ethnomathematics: A dialogue. Learn. Math. 1994, 14, 36-43.

42. Nugroho, S. The aesthetics effect of surakarta-style pakeliran on East Javanese pakeliran. Harmon. J. Arts Res. Educ. 2018, 18, 153-161. [CrossRef]

43. Petersen, R. The Character of the kafir: Domains of evil in the wayang golek menak of Central Java. Asian Theatre J. 1994, 11, 267-274. [CrossRef]

44. Sutiyono, S.; Rumiwiharsih; Suharjana, B. Pemuliaan tanaman padi melalui pertunjukan wayang kulit dalam upacara bersih desa di geneng, trucuk, klaten, Jawa Tengah. Mudra J. Seni Budaya 2018, 33, 263-276. [CrossRef]

45. Sulaksono, D. Filosofi pertunjukan wayang purwa. Ibda J. Kajian Islam Budaya 2013, 11, 238-246. [CrossRef]

46. Junaidi, J.; Haryono, H. Merancang boneka wayang remaja. Lakon J. Pengkaj. Pencipta. Wayang 2008, 5, 1-10.

47. Haryadi, T.; Khamadi. Perancangan model wujud visual tokoh pewayangan dalam pembentukan identitas dan watak tokoh sebagai acuan desain karakter dalam karya DKV. DeKaVe 2014, 7, 56-77. [CrossRef]

48. Walpole, R.E. Pengantar Statistika; Gramedia Pustaka Utama: Jakarta, Indonesia, 2010.

49. Evans, M.J.; Rosenthal, J.S. Probability and Statistics: The Science of Uncertainty; Macmillan: New York, NY, USA, 2004.

50. Ras, J.J. The social function and cultural significance of the Javanese Wayang Purwa theatre. Indones. Circ. 1982, 10, 19-32.

51. Handayani, C. The re-animation of the traditional folk arts as the ancestors cultural heritage at bukit menoreh bhumi sambhara budhara. Harmon. J. Arts Res. Educ. 2006, 7, 1-12.

52. Wright, L. Indonesia: Myth and reality in the land of the shadow puppet. Int. Stud. Manag. Organ. 1994, 24, 35-60. [CrossRef]

53. Pandin, M.G.R. Moral-ethics-belief values towards Indonesian puppet (Wayang kulit) performance arts. Utop. Prax. Latinoam. 2020, 25, 515-521.

54. Jimat, J. Perspektif Pendidikan Islam Terhadap Ajaran Hastha Brata Dalam Wayang Kulit Serta Relevansinya Dengan Pendidikan Masa Kini. Undergraduate Thesis, IAIN Walisongo, Semarang, Indonesia, 2008.

55. Kasim, S. Wayang dalam kajian ontologo, epistimologi dan aksiologi sebagai landasa filsafat ilmu. J. Sangkareang Mataram 2018, 4, 47-50.

56. Siswanto, N. Perubahan pandangan ontologi pada wayang masa islam dan pra islam. J. Filsafat 2017, 27, 106-118. [CrossRef]

57. Hadiprayitno, K. Tontonan, tatanan, dan tuntunan aspek penting dalam aksiologi wayang. In Proceedings of the Sarasehan Senawangi Kongres IX Senawangi, Cipayung, Jakarta, 25-26 April 2017.

58. Sabunga, B. Nilai-nilai karakter dalam pertunjukan wayang golek purwa. Sosio Religi J. Kajian Pencipta. Umum $2016,14,1-12$.

59. Suparjo. On land (wealth) distribution: A cultural approach to justice in Indonesia. Indon. L Rev. 2011, 1, 334-348. [CrossRef]

60. Trivedi, S. Early Indian influence in Southeast Asia: Revitalizing partnership between India and Indonesia. India Q. 2010, 66, 51-67. [CrossRef]

61. Lim, S.L. Transmitting the Ramayana Epic from India to Southeast Asia and the West through Shadow Puppetry and Visual Art; Northern Illinois University: DeKalb, IL, USA, 2010.

62. De Lange, J. Using and applying mathematics in education. In International Handbook of Mathematics Education; Springer: Dordrecht, The Netherlands, 1996; pp. 49-97.

63. Van den Heuvel-Panhuizen, M.H.A.M. Assessment and Realistic Mathematics Education; Utrecht University: Utrecht, The Netherlands, 1996; Volume 19, pp. 9-272.

64. D'Ambrosio, U. Ethnomathematics and its first international congress. ZDM 1999, 31, 50-53. [CrossRef]

65. Psomos, P.; Kordaki, M. Pedagogical analysis of educational digital storytelling environments of the last five years. Procedia Soc. Behav. Sci. 2012, 46, 1213-1218. [CrossRef]

66. Soerjoatmodjo, G.W.L.; Kaihatu, V.A.M. Family decision-making process on cultural heritage appreciation in Akhir Pekan@ Museum Nasional. Procedia Soc. Behav. Sci. 2016, 222, 539-547. [CrossRef]

67. Dhari, Y.W. Pewarisan keahlian mendalang pada keluarga dalang wayang golek abah sunarya. Umbara 2019, 4, 130-140. [CrossRef]

68. Prahmana, R.C.I.; D'Ambrosio, U. Learning geometry and values from patterns: Ethnomathematics on the Batik patterns of Yogyakarta, Indonesia. J. Math. Educ. 2020, 11, 439-456. [CrossRef]

69. Supiyati, S.; Hanum, F.; Jailani. Ethnomathematics in Sasaknese architecture. J. Math. Educ. 2019, 10, 47-58. [CrossRef] 